\title{
Community Connections: Employee Volunteering ${ }^{1}$
}

\section{Marilyn K. Lesmeister and Anne Romero. ${ }^{2}$}

The workplace is an excellent place to promote volunteerism and recruit volunteers.

Whether it is a small, local business, or large, national corporation, employees can be a source of volunteer power in any community. Employees can participate in a wide range of volunteer activities and programs that are supported by their employers. Employee volunteers are often equipped with specialized skills, information, and a fresh perspective to help address community issues and challenges (Lautenschlager, 1993). There can be benefits to the individual employee, the employer, the corporation, and the community.

Live and work to make a difference, to make things better, even the smallest things. Give full consideration to the rights and interests of others. No business is successful, even if it flourishes, in a society that does not care for or about its people. -Eugene C. Dorsey

\section{What is Employee Volunteering?}

As a relatively new and growing field, the terms related to volunteering through one's workplace have not been firmly established. You may hear the terms employee volunteering, corporate volunteering, employer-supported volunteering, and workplace volunteering used interchangeably. While there are distinct differences between them, the basic idea is that "employees perform work in the community with some form of support and/or encouragement from their employer" (Graff, 2004). Each of the four key terms are defined below.

Employee volunteering refers to employees who participate in volunteer activities through their workplace. Employers encourage and support these activities and create a volunteer friendly workplace-an environment where volunteer activity is valued and recognized. It is almost always employee-driven and directed and done on employees' own time.

Corporate volunteering is a formal or organized process that a company uses to encourage and support volunteering efforts by its employees and retirees during work hours.

Some retirees enjoy ongoing contact with friends and colleagues, so they may become part of the corporate volunteer program. The company extends good relationships to the community through its current employees and retirees.

1. This document is FCS9235, one of a series of the Family, Youth and Community Sciences Department, Florida Cooperative Extension Service, Institute of Food and Agricultural Sciences, University of Florida. Original publication date December 2005. Visit the EDIS Web Site at http://edis.ifas.ufl.edu.

2. Marilyn K. Lesmeister, 4-H Volunteer Development Specialist, Department of Family, Youth and Community Sciences, University of Florida, Gainesville, Fl 32611 and Anne Romero, Graduate Student, Department of Health Education and Behavior, University of Florida, Gainesville, FL 32611.

The Institute of Food and Agricultural Sciences (IFAS) is an Equal Opportunity Institution authorized to provide research, educational information and other services only to individuals and institutions that function with non-discrimination with respect to race, creed, color, religion, age, disability, sex, sexual orientation, marital status, national origin, political opinions or affiliations. U.S. Department of Agriculture, Cooperative Extension Service, University of Florida, IFAS, Florida A. \& M. University Cooperative Extension Program, and Boards of County Commissioners Cooperating. Larry Arrington, Dean 


\section{Employer-Supported Volunteering refers to a} continuum of employer support for employee volunteer activities and community involvement. Generally, volunteer initiatives are incorporated into the workplace and involve various levels of employer involvement (Graff, 2004).

Workplace Volunteering refers to a company's voluntary support of their employees volunteer activities and community involvement. According to the National Work-Life Alliance (2002), an ideal workplace volunteer program should contain elements of both employee volunteering and corporate volunteering. Table 1 highlights the differences between the two.

\section{Benefits to the Corporation}

Research shows that "one of the most effective methods of enhancing a corporations public image is through the contributions of time and talent from employees" (Peterson, 2004). Companies reap many benefits from employee volunteer efforts including:

- improved relations with the surrounding community,

- enhanced public image,

- enhanced corporate image (socially responsible corporate image),

\begin{tabular}{||l|l||}
\hline \hline Table 1. & \\
\hline \multicolumn{1}{|c||}{ EMPLOYEE / RETIREE VOLUNTEERING } & \multicolumn{1}{c||}{ CORPORATE VOLUNTEERING } \\
\hline - Done on employee(s) own time & $\bullet$ Happens during business hours \\
\hline - Opportunity for employees to work together & $\begin{array}{l}\text { - Might be an opportunity for employees to do } \\
\text { volunteer work together }\end{array}$ \\
\hline $\begin{array}{l}\text { - Sometimes facilitated by the company; sometimes } \\
\text { facilitated by the employee(s) }\end{array}$ & $\begin{array}{l}\text { - Generally facilitated by the company with clear } \\
\text { objectives for the event/project }\end{array}$ \\
\hline - Top down or bottom up, NOT on company time & \begin{tabular}{l} 
Top down or bottom up, IS on company time \\
\hline $\begin{array}{l}\text { - Can be encouraged, promoted, recognized and/or } \\
\text { enabled by the company }\end{array}$
\end{tabular} \\
\hline \hline
\end{tabular}

Volunteer programs in the workplace are most successful when they are based on "integrating the priorities of the company, the interests of the employees, and the needs of the community" (Points of Light Foundation, 1996). These programs help businesses become leaders in their communities. While the needs of the community are being addressed, employee volunteers are feeling the rewards of community involvement, the corporation receives recognition, and the base of volunteers available to a non-profit organization grows.

\section{The Benefits of Employee Volunteering}

Employee volunteer programs provide many benefits to businesses, employees, retirees, non-profit organizations, and communities.
- a positive impact on employee morale and stronger employee commitment,

- improved internal communication,

- improved sense of team spirit,

- a healthier economic and social environment,

- increased ability to attract and retain high-quality employees.

A business can also benefit from an employee volunteer program because it encourages relationships. Strong relationships among employees, between departments, and between employees and their families are valuable to everyone. When these relationships are nurtured, employees are usually more satisfied with their work life. If employees feel connected to their employer, one or more of these relationships are promoted. Employees can be more satisfied when they see that the corporation they work for is connected to the community they live in. 


\section{Benefits to Employees and Retirees}

Retired employees can be a strong source of support in a corporate volunteer program. Employees and retirees benefit from:

- pride and loyalty for their company,

- sense of fulfillment, contributing to community,

- learning new skills to enhance career, personal development, career growth (Ex: communication skills, time management, teamwork, planning),

- leadership and skill development,

- networking opportunities,

- increased community awareness.

\section{Benefits to the Non-Profit Organization}

- Corporations become sources of active, skilled volunteers who bring new talent, ideas, and energy.

- Partnerships with employee volunteer programs help build the skills of non-profit staff members (long-term benefit).

- A partnership with an employee volunteer program also creates an opportunity to educate corporate volunteers about the non-profit's mission.

\section{Benefits to Communities}

- Increased resources come to the community through businesses and organizations.

- There is increased rapport and understanding between corporations and the non-profit sector.

- The quality of life within the community is enhanced.

- Financial/philanthropic donations are stronger.

\section{Recruiting Participation in an Employee Volunteer Program}

Building strong relationships is important to developing an effective partnership between an employee volunteer program and a non-profit or community organization. Some volunteer programs may be corporate-sponsored while others may be employee-driven (Merrill Associates, 2001).

Volunteers who represent a corporation can be recruited from the current employee base, employee families, retirees, foundation members, advisory members, and even clientele.

When encouraging employee participation in a volunteer program beware of "overselling the program" (Peterson, 2004). Employees will not respond well to feeling pressured to participate and may end up not seeing the opportunity as voluntary.

\section{Conclusion}

Employee volunteer programs can benefit the corporation, employees, the community, and local non-profit organizations. These programs can be initiated by employees, the corporation, or a non-profit organization. Employee volunteer programs can be successful as long as there is a shared vision, mutual goals, valued work, with visibility and real benefits.

\section{References}

Graff, L. (2004). Making a Business Case for Employer-Supported Volunteerism, Volunteer Canada.

Lautenschlager, J. (1993). Volunteering in the Workplace: How to Promote Employee Volunteerism, Voluntary Action Directorate, Department of Canadian Heritage.

Merrill Associates: Strengthening Leaders, Organizations and Communities. (2001). Building Relationships to Engage Corporate Volunteers. Retrieved May 6, 2005, from http://www.merrillassociates.net/topic/2001/07/01/ building-relationships-to-engage-corporatevolunteers/

National Work-Life Alliance. (2002). A Work-Life Tool: Leadership Development Through Corporate Volunteerism: An Innovative Approach to Developing Innovative Leaders. Retrieved May 18, 2005, from 
http://worklifealliance.org/tools/volunteer/ index.cfm.

Points of Light Foundation. (1996). Developing a Corporate Volunteer Program. Washington D.C.

Peterson, D. K. (2004). Recruitment strategies for Encouraging Participation in Corporate Volunteer Programs. Journal of Business Ethics, 49, 371-386. 